\title{
Wang, Jackie (2018), Carceral Capitalism
}

João Gabriel

\section{(2) OpenEdition}

\section{Journals}

Electronic version

URL: https://journals.openedition.org/rccs/10002

DOI: $10.4000 /$ rccs. 10002

ISSN: 2182-7435

\section{Publisher}

Centro de Estudos Sociais da Universidade de Coimbra

\section{Printed version}

Date of publication: 1 December 2019

Number of pages: 209-211

ISSN: 0254-1106

\section{Electronic reference}

João Gabriel, "Wang, Jackie (2018), Carceral Capitalism", Revista Crítica de Ciências Sociais [Online], 120 | 2019, Online since 12 December 2019, connection on 20 July 2022. URL: http:// journals.openedition.org/rccs/10002 ; DOI: https://doi.org/10.4000/rccs.10002

Creative Commons - Attribution 4.0 International - CC BY 4.0

https://creativecommons.org/licenses/by/4.0/ 


\section{Recensões}

\section{Wang, Jackie (2018), Carceral Capitalism. South Pasadena: Semiotext(e), $360 \mathrm{pp}$.}

In a May 2018 interview with the Los Angeles Review of Books ${ }^{1}$ concerning her book, Carceral Capitalism, Jackie Wang was asked to summarize the link between the phenomenon of racialized mass incarceration and the seemingly omnipresent debt economy, which takes a central role in the book. Resolutely, the performer, poet and Harvard $\mathrm{PhD}$ candidate replied that she "wanted to think of debt as a form of unfreedom that is unequally distributed". One can hardly oppose this definition, for, in her book, the author goes as far as to state that, in writing these essays, she wanted to show "how carceral techniques of the state are shaped by - and work in tandem with - the imperatives of global capitalism" (p. 69). Furthermore, she asserts that "Carceral Capitalism is not an attempt to posit carcerality as an effect of capitalism but to think about the carceral continuum alongside and in conjunction with the dynamics of late capitalism" (p. 85), which becomes connected with one of Wang's main theses, i.e. that "black racialization proceeds by way of a logic of disposability and a logic of exploitability" (p. 88). Taking a page from Wolfgang Streeck, Wang writes that in a quintessentially neoliberal context, the evolution of the tax state into a debt state generates the necessary conditions for the emergence of a predatory state. In other words, neoliberalism has led to the collapse of the tax state which inextricably tied the sustainability of government bodies to the creation of debt which, in turn, whenever payments are due, means that revenue must be secured, this time from the very population the government itself proposed to represent. As such, debt is at the core of Wang's concerns with the contemporary racialized nature of the Prison Industrial Complex, in which mass incarceration takes a particularly heavy toll on black and Latino minorities. Time and again, the author reiterates the notion that, as a result of the increasing hegemony of debt economy, the government and its officials have shifted their priorities from the public that elected them to the financial institutions to which they are largely indebted. The author substantiates this by referring to the analysis of, for instance, David Harvey, who, quoted in this volume, bluntly states that "[i]f there is a conflict between the well being of financial institutions and the well being of the population, the government will choose the well being of the financial institutions; to hell with the well being of the population" (p. 164). This means that if the financial sector supports public debt then the government becomes far more accountable to its creditors than to the public. Debt thus becomes a de-democratizing agent in which the higher the debt, the lower an individual's (credit) worthiness, which will eventually strip them of their fundamental rights, increasing the probability that they will become

${ }^{1}$ Buna, M. (2018), "Carceral Capitalism: A Conversation with Jackie Wang”, Los Angeles Review Of Books, May 13. Accessed on 09.09.2019, at https://lareviewofbooks.org/article/ carceral-capitalism-conversation-jackie-wang/. 
a target for predatory fees and, eventually, incarceration. To make matters worse, when debt itself is turned into a highly profitable commodity, then the aforementioned demographics become an actual source of revenue. This was made particularly clear in the aftermath of the 2008 subprime mortgage crisis that saw the profitization of debt taken to never-before-seen extremes. The collapse of the housing market generated a global economic crisis, which led to the defunding and loss of revenue for municipalities that, in turn, resorted to the "creation of municipal fiscal schemes" (p. 19) to make-up for their losses. The public thus becomes an alluring source of revenue, and police departments are used as a tool for extracting valuable income - a process the author does not shy away from bluntly (and aptly) denouncing as "looting" (p. 22). Through these mechanisms, police departments are used "to plunder residents" (p. 19) and, unlike other public sectors, they "continue to operate" and "are among a meager handful of unions that have actually fared well" (p. 19), mainly due to what has been designated "offender-funded policing", similarly replicated in the court systems, wherein offenders are forced to pay various fees to cover the expenditures of their constitutionally inalienable right to due process (public defender fees, arrest fees, prison housing fees, etc.). Furthermore, in the context of a global financial crisis with debt at its core, it becomes understandably more profitable to invest in prisons rather than in social programs, thus starting a vicious cycle in which, from a socioeconomic standpoint, historically disadvantaged minorities will be further hindered. But this is not new information and, as of late, it has found an audience.
A considerable portion of the subjects approached by the author in this collection of essays has recently found its way into the public eye, largely at the hands of widely-watched shows such as HBO's Last Week Tonight in which, weekly, comedian John Oliver approaches a problematic subject to discuss at length, always grounding his exposition with extensive and rigorous research. Interestingly, one of the examples Wang draws upon to showcase the near-kafkian horror generated by the aforementioned predatory practices both by police and the court system is the exact same one Oliver used in a fairly recent show about municipal violations, ${ }^{2}$ wherein a man was forced to sell his own blood plasma to be able to make payments on the fees imposed by the court and the police department over a minor offense. Wang has no shortage of examples and deftly navigates her material by establishing a comfortable pace made possible by a delicate balance between academic discourse as such and human-interest stories, sometimes taken from her own biography. Indeed, quite refreshingly, Wang often resorts to illustrating her points with vivid personal anecdotes. What she tells the reader regarding both her brother's experience of imprisonment and her own interactions with him from the perspective of a free individual are more than enough to put the extensive amounts of theoretical exposition that preceded this account into much-needed context. This way, a reader is better able to witness first-hand the differences between life in prison and life on the outside. Beyond simple physical separation between free people and convicted offenders, it could be argued that serving time in prison creates a division that resembles something along the lines

\footnotetext{
2 "Municipal Violations: Last Week Tonight with John Oliver (HBO)”, Youtube, March 22, 2015. Accessed on 09.09.2019, at https://www.youtube.com/watch?v=0UjpmT5noto.
} 
of time being stopped altogether. It can hardly be expected that someone who spends years isolated from society will be able to cope with the hectic pace of, for instance, technological development. It is in these more personal notes that some of Wang's most inspiring glimpses of formal innovation come into play.

While most of the chapters in the volume read as conventional essays, Wang innovates through carefully thought-out and aptly placed inserts that, in what seem to be excerpts taken from some sort of personal journal, read very much like poetry (another medium the author explores regularly). In what is perhaps the less usual of all the essays, chapter five (titled "The Cybernetic Cop: Robocop and the Future of Policing”), Wang adapts for example "a multimedia performance originally conceived for the L.A Filmforum's Cinema Cabaret" (p. 253; italics in the original) into a somewhat lighter chapter that follows a highly expositive essay on predictive and algorithmic policing.

As a whole, by placing her work in a thoroughly researched cross-section of post-marxist economic theory and analysis - prison abolitionist thinking framed by great bastions of African-American thought such as W. E. B. Du Bois, and something approaching the realm of poetry and performance that gives the volume a more human and perhaps more real and concrete reality, without ever facilitating the appropriately serious nature of her subject matter - Jackie Wang has succeeded in crafting an inspiring set of essays that shed light on some of the society's most pressing concerns that, as of late, have rightly begun to seep into public consciousness and that, aside from deserving everyone's undivided attention, proves yet again that, yes, the game is rigged.

João Gabriel

\section{Giuliani, Gaia (2016), Zombi, alieni e mutanti. Le paure dall'11 settembre a oggi. Firenze: Le Monnier, 200 pp.}

\section{To Live with the Monsters}

In this world that lost its utopias and their projection of perfect and (im) possible worlds into the space-time continuum, dystopian narratives are the representations and the key to understand contemporary time and its fears. In this age devoid of a world order, political directions and, after 1989, temporal perspective towards the future, natural and human catastrophes, "internal" and "external" monsters, as well as the thinning of the borders between natural and artificial besiege our imaginary and define outlines, meanings and references. The obsession with security in a time without future and dreams, through the continuous production of threatening diversities, identifies and constrains the political objectives with the sole task of protecting and preserving the human species, the nation, the community, the family, private property; protecting the circulatory system of the social structure - that is the capitalist system of private production and consumption - from potential and imaginary pathogenic germs. A system, by its nature based on the competitive principle of inclusion/exclusion, that at the same time protects, nourishes, consumes, devours and destroys human life. In this political and social scenario, an evident shift in social attention towards the 
visual media sphere - due to its "ability to arouse strong emotions" (p. 3) and its "very high commercialization" (ibidem $)^{1}$ - makes this dimension not only the main space of construction of collective imagination, but even the space where reality itself is produced; its hyper-realistic dimension arises from the confusion between real content, representations and media aspects, as Gaia Giuliani highlights in this book on the monstrous figures of otherness: Zombie, alieni e mutanti.

The references to gender studies, post-human feminist philosophy and race studies of the last years - particularly to whiteness studies - provide key tools and work materials for the intersectional approach chosen by Giuliani, in this and other researches, to develop her articulated and comprehensive criticism of the current system of global domination.

With this critical interpretation of the present times, Giuliani's research reconstructs the visual archive of contemporaneity, accessing this extreme space of representation of nightmares and real distortions of our imaginary: an exciting journey through science fiction, horror movies and TV series produced in the Western world in recent years.

It is a work of semiotic deconstruction of movie language, and at the same time a philosophical-political text. It is an interpretation of the present contextualized with the history of the last two centuries. Giuliani's point of view is crucial: the ghosts summoned in our confusing time to terrify us and to close ourselves to diversity actually come, like every good nightmare, from our past. This horizon is clarified and reconstructed with great analytical ability in this book.
It focuses above all on the colonial past, its semantics and image repertoire as a space where the West has built and fed from its heritage of monstrous others. Current visual literature thus draws on the cultural heritage of a system of domination, which Giuliani analyzes with special and constant attention in her philosophical investigation on the production of racisms. Despite the gigantic work of historiographical revision of the last decades that has brought to the surface all the "barbaric" violence carried out by the conquerors in the colonial past, living dead, anthropophagous monsters and insidious aliens continue to emerge from the past, sprung from racial genealogies; from that far world they rise to come and threaten and devour the "innocent" peace of our families and society. A continuous narrative of violent scenarios emerges, and so a political and social clash, vital and relevant, between civilizations and for civilization breaks out, the same one that fueled Western expansionism in the world for two centuries. Once more the national community, as an imagined community, is rebuilt through the monstrification of the other and the confirmation of its own endeavor towards progress, peace, and civilization. But, in this visual patrimony, the neocolonial representation of monstrous otherness also takes the form of the attention to physical and psychic alterations until one can identify a post-human dimension in the relationship between the human being and nature, and the human being and technology. Once more, the political objective is to take control over mutations, diversities, racial mixings, and indistinctness.

The careful analysis of movies production, on which this research is based, shows that

\footnotetext{
${ }^{1}$ Translations by the author.
} 
the visual material examined is not only the expression, but rather the live food, so to speak the active and socially performing element of a view of the present world and the future of humanity that is clearly claustrophobic and apocalyptic, and that in the end seems to want to leave us without any chance for social change.

Giovanni Ruocco

Edited by Ricardo Cabrita

\section{João Gabriel}

Reasearch assistant, Project CILM - Centro de Estudos Comparatistas, Faculdade de Letras da Universidade de Lisboa (FLUL) I Student of the Master's Degree in Comparative Studies, FLUL

Alameda da Universidade, 1600-214 Lisboa, Portugal

Contact: jmpalaio@gmail.com

ORCID: https://orcid.org/0000-0002-2704-7752

\section{Giovanni Ruocco}

Sapienza Università di Roma

Piazzale Aldo Moro 5, 00185 Roma, Italy

Contact: giovanni.ruocco@uniroma1.it ORCID: https://orcid.org/0000-0002-2248-0477 
